УДК:741.5:32:004.9[327:355 (470)]

ПИТЛЬОВАНА Л. Ю.

http://orcid.org/0000-0002-5700-9992

БУРАКОВ Я. Ю.

https://orcid.org/0000-0002-8572-3253

https://doi.org/10.33577/2313-5603.31.2019.206-224

\title{
УКРАЇНА, РОСІЯ І СВІТОВА БЕЗПЕКА У КАРИКАТУРІ ДЕРІЛА КЕЙГЛА ТА ІНТЕРНЕТ-РЕСУРСУ САGLЕ CARTOONS
}

У статті розкриваються особливості репрезентації подій в Україні, починаючи 32004 р., та російсько-українського збройного конфлікту 2014-2019 років у політичній карикатурі інтернет-ресурсу Cagle Cartoons та американського карикатуриста Деріла Кейгла (Daryl Cagle). Проаналізовано 520 карикатур ресурсу, виокремлено і систематизовано основні тематичні блоки, висвітлені у сюжетах політичних карикатур. Проаналізовано найпоширеніші концептуальні графічні метафори, образи України, Росії та країн Заходу у контексті російсько-українського конфлікту, а також ставлення художників-карикатуристів до зображуваних подій.

У результаті дослідження встановлено, що спільними особливостями карикатур є чітко виражена, незалежно від національної приналежності художника, антиросійська позиція; представлення України як жертви російської агресії; підкреслення злочинного характеру дій В. Путіна та російських військ у Криму та на Сході України; виражений гендерний дискурс малюнків (Україна репрезентується як жінка, Росія - як чоловік (найчастіше - В. Путін), створюючи бінарну опозицію «слабкість - сила»). Більшість малюнків розглядають українсько-російську війну не лише як локальний конфлікт, який становить загрозу інтересам і безпеці України, а у значно ширшому безпековому контексті.

Ключові слова: безпека, політична карикатура, українсько-російський збройний конфлікт, Cagle Cartoons, Daryl Cagle.

Постановка проблеми та стан ї̈ дослідження. Поле сучасних історичних досліджень має в своїй основі широку джерельну базу, важливою частиною якої є візуальні матеріали. Візуальний поворот породив також розвиток методології роботи 3 візуальними джерелами.

Питльована Лілія Юріївна, кандидат історичних наук, доцент, доцент кафедри світової історії нового і новітнього часу Українського католицького університету, м. Львів.

Бураков Ярослав Юрійович, студент 4-го курсу Інституту комп'ютерних наук та інформаційних технологій Національного університету «Львівська політехніка», м. Львів.

(С) Питльована Л.Ю., Бураков Я.Ю., 2019 
Політична карикатура, переживши пік своєї популярності у період домінування паперових засобів масової інформації, не втрачає свого значення і сьогодні. Вона є важливим елементом побудови інформаційної моделі навколо тієї чи іншої проблеми, події, особи в інтернет-3МІ та соціальних мережах, продукування відповідного дискурсу. Репрезентація інформації візуальними методами не лише слугує вдалим доповненням текстового матеріалу, а й часто промовляє до реципієнта білыш наочно. За словами американського художника Мета Воркера, карикатуристи дають серйозні коментарі на серйозні теми несерйозними засобами (Підсумки року, 2018). Карикатура спонукає читача мислити образно і критично, а відчитування карикатури дає йому емоційне задоволення, можливість власної інтерпретації відображеного у ній сюжету. Водночас, будучи репрезентацію уявлень художника, карикатура спрямовує читача до бажаної оцінки запропонованої інформації.

Тема висвітлення російсько-українського конфлікту у політичній карикатурі частково представлена у дослідженнях Католи В. (Катола, 2017), Ходаківського М. (Ходаківський, 2015), ЯцимірськоїМ. (Яцимірська, 2015), проте докладного аналізу рефлексії американської карикатуристики на згадану тематику не існує.

Актуальність дослідження зумовлена важливістю дослідження репрезентації карикатуристами США подій російсько-українського конфлікту, донесення ними свого бачення до широкого читача $\mathrm{i}$ впливу, таким чином, на формування відповідної громадської думки. Критично-сатиричний погляд на агресію Росії щодо України і його дослідження особливо важливі в умовах ведення Російською Федерацією широкомасштабної інформаційної війни проти України і можуть слугувати засобом ефективної протидії інформаційним маніпуляціям окремих держав. Особливого значення у даному контексті набувають інтернет-ресурси, такі як Cagle Cartoons, з огляду на можливості масового доступу до них.

Метою статті є аналіз особливостей відображення у політичній карикатурі Деріла Кейгла та інтернет-ресурсу Cagle Cartoons причин, перебігу та наслідків російсько-українського збройного конфлікту 2014 - 2019 років.

Виклад основного матеріалу. Однією 3 найважливіших рис політичної карикатури $є$ іiї актуальність. Вона означає відповідність у часі сюжету малюнка певним подіям у внутрішній чи зовнішній політиці, а також відповідність рівню зацікавленості цими подіями 
тієї аудиторії, для якої карикатура призначена. Таким чином, можлива ситуація, коли політична подія чи процес все ще тривають, однак втрачають важливість для художника, громадської думки, політиків, урядовців, їх місце займають злободенніші проблеми. У таких випадках спостерігається поступовий чи різкий спад кількості карикатур, публікованих на певну тему. Різке їх зменшення відбувається також тоді, коли події у гарячій точці починають набувати характеру хронічного конфлікту 3 нечіткою перспективою його розв'язання.

Одним із прикладів спаду синусоїди зацікавленості карикатуристів є українсько-російський конфлікт. Амплітуда їхнього інтересу сягнула піку в період російської агресії проти України 2014 р., а станом на початок 2019 р. ми можемо спостерігати цілковитий його спад.

Свого часу нами уже досліджувався сайт друкарського і цифрового синдикату (Print and digital syndicate) Cagle Cartoons (http://www.caglecartoons.com). Корпорація була створена 2001 p. Дерілом Кейглом (Daryl Cagle) (нар. 1956 р.), одним із найбільш плідних сучасних американських карикатуристів. Маючи понад 3 млн унікальних відвідувачів щомісяця, сайт є одним із найбільших інтернет-ресурсів політичної карикатури США. Синдикат розповсюджує малюнки 127 провідних карикатуристів та 9 оглядачів (фейлетоністів) (близько 20 лауреатів Пулітцерівської премії у більш як 850 передплатних газет США (3 них понад половина щоденних) та світу (Питльована, 2016). Серед найвідоміших карикатуристів, членів синдикату - Adam Zyglis («Buffalo News», «Washington Post»), Пулітцерівська премія 2015 р.; Steve Sack («Minneapolis Star Tribune»), Пулітцерівська премія 2013 р.; Mike Keefe («Denver Post», «Colorado Independent»), Пулітцерівська премія 2011 р.; Stephen Paul Breen («San Diego Union-Tribune»), Пулітцерівська премія 1998 і 2009 pp.; Michael Ramirez («Los Angeles Times», «USA Today»), Пулітцерівська премія 1994 і 2008 pp.).

Бізнес-модель корпорації базується на принципі «package service» («пакетний сервіс»), коли видавництва-передплатники отримують необмежений доступ і право на необмежені публікації карикатур ресурсу за єдину плату. У такий спосіб найкращі карикатури можуть бути швидко передруковані у багатьох світових виданнях, i ïx можуть оглядати мільйони читачів (Tornoe). 
Засновник синдикату Д. Кейгл розпочав свою творчу кар'єру після закінчення коледжу Каліфорнійського університету в СантаБарбарі і переїзду в Нью-Йорк наприкінці 1970-х років. Упродовж п'ятнадцяти років Деріл працював художником у The Jim Henson Company, випускаючи славнозвісні «Маппети» (The Muppets), ілюструючи численні книги, журнали, календарі та іншу друковану продукцію, пов'язану з шоу. Впродовж цього часу він також залучається до створення рекламних кампаній відомих компаній, зокрема, McDonalds, працює винахідником і дизайнером дитячих іграшок, ігор та книжок.

3 середини 1990-х років Д. Кейгл зосереджується на політичній карикатуристиці. Його щоденні редакторські карикатури можна було бачити у виданнях Tribune Media Services, Midweek Newspaper, The Honolulu Advertiser. Упродовж 2000 - 2005 рр. він малює для інтернет-видання Slate.com, що тоді належало The Washington Post Company (Daryl Cagle bio). Це новинне видання спеціалізується на висвітленні поточних подій, політиці, культурі. 32005 р. Д. Кейгл працює карикатуристом телеканалу MSNBC. Він був створений 1996 р. спільно компаніями Microsoft та відділенням американської Національної телерадіомовної компанії NBC, і є доступним глядачам із США, Канади, Південної Африки та Близького Сходу. Від 2010 p. MSNBC неодноразово випереджає за рейтингами свого головного конкурента телеканал CNN. Гаслами каналу MSNBC є «Місце для політики» («The Place For Politics») та «Виявляти ініціативу!» («Lean Forward!») (з 2010 р.), а тематичними пріоритетами політика та новини. Канал позиціонує свій ухил до лівої політики та Демократичної партії (Питльована, 2016, с. 136). Впродовж короткого часу Д. Кейгл також був президентом Національного товариства карикатуристів США.

Методологія нашого аналізу карикатур ресурсу Cagle Cartoons базується на деконструкції та інтерпретації образів, які є ключовими елементами кожної з них, тлумачення метафоричних моделей, символів та алегорій, аналогій, застосованих для відображення тієї чи іншої події чи особи. Необхідним завданням також є деконтекстуалізація малюнків, узгодження 3 політичними подіями українськоросійського конфлікту та проблемами національної, регіональної та світової безпеки, зіставлення офіційного та медіадискурсу країн Заходу щодо подій в Україні та з'ясування, як він проявляється в карикатурі. Важливим показником є також кількість і частота появи карикатур на досліджувану тематику. 
Можемо констатувати, що карикатуристи Cagle Cartoons мали інтерес до подій в Україні, починаючи з 2004 р., однак лише російська збройна агресія проти України спричинила різке збільшення кількості малюнків на українську тематику. Так за пошуковим тегом «Україна» з листопада 2004 до лютого 2019 р. виявлено 520 карикатур. 3 них 6 стосуються подій Помаранчевої революції, 33 - різних подій в Україні у період з 2006 до листопада 2013 р., 47 присвячені подіям Євромайдану і 434 карикатури - російсько-українському конфлікту. Останні найбільш часто виходять у 2014 р. - 329, а потім спостерігається поступове згасання зацікавленості художників подіями в Україні: 2015 р. - 68 карикатур, 2016 р. - 11, 2017 р. - 7, невелике зростання у 2018 р. - 17, а за перші два місяці 2019 р. - 2. Найбільше уваги подіям в Україні приділяли карикатуристи, які представляють видання США, Нідерландів, Австрії, Словаччини, Болгарії, Румунії.

Для кращої систематизації карикатур нами був здійснений відбір за додатковими пошуковими тегами, такими як «безпека», «війна», «перемир'я» «сепаратизм», «тероризм», «НАТО», «Крим», «СС», «зброя», «Путін», «Росія». Аналіз відібраних карикатур дозволив з'ясувати наступне. $2014-2015$ рр. стали періодом посиленої уваги карикатуристів Cagle Cartoons до ситуації в Україні, у часі їхні малюнки з'являються синхронно до подій в Україні й довкола неї. Більшість малюнків розглядають українсько-російську війну не лише як локальний конфлікт, який становить загрозу інтересам і безпеці України, а у значно ширшому безпековому контексті.

Відповідно до порушуваної у карикатурах тематики їх можна згрупувати у декілька блоків:

1) Порушення Росією територіальної цілісності і суверенітету України тлумачиться як руйнування підвалин ЯлтинськоПотсдамської системи міжнародних відносин, а отже, і як загроза загальноєвропейській безпеці (Ukraine redrawing borders,2014; Putin stalks his prey, 2014). Часто використовуваною персоніфікацією Росії на цих малюнках є ведмідь, який чи то переступає кордон України, чи то топче і шматує український прапор - символ державності, чи переміщує на користь Росії прикордонні стовпщі (Ukraine and the bear, 2014; Ucraine by Pavel, Russian appetite, 2014).

2) Захоплення Росією Криму та включення півострова до складу Російської Федерації презентується авторами карикатур як анексія, акцентується увага на цілковитій незаконності і нелегітимності 
проведення референдуму в березні 2014 р. у Криму. На малюнках найчастішим уособленням Росії виступає президент В. Путін (яскравий приклад - образ Путіна-злодія, який поцупив український Крим (Thief Putin, 2014). Автори активно використовують інтернет-мем і евфемізм «зелені чоловічки» на означення російських військових у камуфляжах без розпізнавальних знаків, які забезпечили проведення псевдореферендуму, захоплення і окупацію Криму (Crimea Referendum, 2014).

3) Початок війни на Сході України карикатуристи пов'язують 3 політикою Кремля, вони акцентують увагу читачів на факті інспірації та підтримки сепаратистських настроїв на Сході України 3 боку Російської Федерації. Малюнки демонструють, що так звані українські сепаратисти - це маріонетки Кремля, а роль головного ляльковика знову відіграє В. Путін (Pro Russia separatists, 2014; Putin and Ukraine separatists, 2014; Putin shares Ukraine, 2014). Окремі автори навіть відверто порівнюють дії Путіна з підбурювання сепаратистських і проросійських прагнень жителів Донецької та Луганської областей і подальшу агресію російських військ 3 політикою А. Гітлера щодо ревізії Версальської системи у міжвоєнний період (Putin Oscar, 2014).

4) Російсько-український конфлікт на Сході України карикатуристи визначають як «гібридну війну». Автори виокремлюють такі iï ознаки, як акумуляція російських військ у безпосередній близькості до державного кордону України; медійна підтримка бойовиків; поставки військової техніки, боєприпасів і амуніції для незаконних збройних формувань на території Донецької та Луганської областей; потужна пропагандистська кампанія з боку російських засобів масової інформації з метою дискредитації київської влади і дезінформації світової громадськості. Художники викривають постачання зброї сепаратистським угрупованням під виглядом гуманітарних конвоїв (Russian aid to Ukraine, 2014). Особливо влучно цю тематику розкриває голландський художник Аренд ван Дам (Russian humanitarian convoy, 2014; Humanitarian mission, 2014; Russian tourists, 2014). Росія у згаданому контексті зображується у ролі вовка в овечій шкурі (Czar in Sheep's, 2014).

5) Інцидент зі збиттям малайзійського літака $\mathrm{MH} 17$ у липні 2014 р. інтерпретується як терористичний акт. Реакція президента Росії на катастрофу і публікацію результатів розслідування Міжнародної групи цивільних журналістів Bellingcat у 2015 р. та спільної 
міжнародної групи слідчих (Австралія, Бельгія, Малайзія, Нідерланди, Україна) у вересні 2016 р. дала карикатуристам черговий привід запідозрити російського лідера у підтримці тероризму і фактичній причетності до смерті сотень загиблих, брехні і лицемірстві. На малюнках В. Путін найчастіше фігурує із закривавленими руками і довгим, як у Піноккіо, носом (у романі Карло Коллоді ніс дерев'яного хлопчика довшав щоразу, як він говорив неправду) (MH17 and Putin, 2014; Innocence, 2014; MH17 looting, 2014, Vladimir,2014; Flight MH17 investigation, 2014).

6) Карикатури зображають проблеми і виклики безпеці України (найчастіше - загроза втрати національного суверенітету, порушення територіальної цілісності, неможливість реалізації євроатлантичних прагнень (EU, Ukraine and Russia, 2014), безпеці Росії (головним чином, економічним і фінансовим наслідкам тривалого інвестування у війну на Сході України (Russian Economy, 2014), безпеці Свропи (загроза російської експансії, енергетичний шантаж з боку Росії (War of sanctions, 2014; South stream, 2014) та світовій безпеці (розв'язання Росією нової «холодної» війни (Russian Bear, 2014).

7) Зусилля $Є С$, ОБСС, НАТО та США щодо протистояння агресії, керованої В. Путіним, Росії проти України, щодо недопущення остаточного зламу повоєнної системи міжнародних відносин розцінюються авторами карикатур як недолугі, недостатні, нещирі, лицемірні, мізерні (Putin dominates, 2014; OSCE hostages, 2014).

За пошуковим тегом «Україна» на ресурсі Cagle Cartoons знаходимо 12 карикатур самого Деріла Кейгла. Усі вони відрізняються винятковою влучністю у висвітленні подій російсько-українського конфлікту. Малюнки, зазвичай, містять небагато текстових коментарів. Художник робить ставку лише на промовисту картинку. Це прийом, до якого вдається більшість сучасних політичних карикатуристів, яким це часто, за словами Енн Тельнас, визнаної художниці політичної сатири, дає можливість виходити за умовний кордон дозволеного (Секрет актуальності карикатуриста, 2019). На 11 з 12 карикатур Деріла уособленням Росії виступає президент В. Путін.

Зацікавленість Д. Кейгла ситуацією в Україні розпочалася ще 3 подій Євромайдану наприкінці 2013 року. Карикатура «Путін розриває Україну» чітко демонструє загрозу сепаратизації Сходу України, спровокованої Росією. Україна в руках Путіна виглядає простою іграшкою, яку можна легко розломити навпіл (Putin Tears 
Ukraine, 2014). Путіна - розпалювача небезпечних настроїв на півночі і на сході України бачимо на карикатурі «Путін і українські зефірки» (Putin and Ukraine marshmallows, 2014). Можна припустити, що автор малюнка робить відсилання до Стенфордського «Зефірного тесту», натякаючи, що Путін не в стані керуватися розумом, а діє лише емоційно та імпульсивно. Наповнений зефіром саквояж Путіна прикрашений зображенням радянської символіки (серп і молот), що підказує читачеві, що всі зусилля Путіна, спрямовані на дестабілізацію ситуації в Україні, зумовлені його бажанням відродження могутності Радянського Союзу. Д. Кейгл підводить читача до думки, що Путін, прагнучи зберегти домінування Росії на всьому пострадянському просторі, радше розв'яже громадянську війну в Україні, ніж допустить її перехід у сферу впливу Заходу, ЄС.

У такій же іпостасі постає президент Росії на карикатурі «Тінь над Україною» (Shadow Over Ukraine, 2014). Цікаво, що тінь Путіна, який ногами заступив на східний кордон України, падає не лише на іiі територію, а й зачіпає сусідні держави - Молдову, Румунію, Угорщину, Словаччину, Білорусь. Д. Кейгл у такий спосіб дає зрозуміти, що агресія Росії проти України - це не локальний конфлікт, це загроза миру і стабільності у всій Центрально-Східній Європі.

Деріл Кейгл не оминув своєю увагою анексію Росією українського Криму (Putin - Ukraine Purse, 2014). На присвяченій цій темі карикатурі художник зобразив Путіна як злодія, який вихопив сумочку (у формі Кримського півострова) з рук переляканої і розгубленої жінки - України. Президент США Барак Обама у вигляді американського копа робить очільнику Росії суворе попередження 3 погрозою змінити своє ставлення до найменш сприятливого.

Проведення референдуму щодо статусу Криму 16 березня 2014 p. Д. Кейгл представляє читачам як перемогу Росії. Путін в образі печерного чоловіка, неандертальця, з великим кийком у руках, тягне за коси здобуту ним жертву - непритомну білявку Україну (Caveman Putin, 2014).

Д. Кейгл не лише дорікає західним демократіям у недостатності підтримки в складний для неї момент. Він засуджує спонсорську допомогу, яку надають Росії великі світові виробники на проведення Зимових Олімпійських ігор у Сочі. На тілі Путіна-спортсмена витатуйована не лише символіка СРСР (серп і молот, карта СРСР), а й назви фірм (Panasonic, Coca Cola, McDonalds, General Electric, Visa, Dow Chemical, Samsumg, Proctor and Gamble, Omega), які 
надали Росії фінансову підтримку в час, коли Україна потерпає від російської агресії. Татуювальник вже зібрався зробити нову наколку у вигляді Криму Путіну, який водночас просить залишити на тілі місце і для усієї України. Тобто автор не сумнівається в тому, що апетити президента Російської Федерації точно не обмежаться Кримським півостровом (Putin Ukraine and Olympic Games, 2014).

Прагнення В. Путіна перетравити всі країни на пострадянському просторі і в результаті «зліпити» 3 них новий СРСР жорстко висміюються Дерілом Кейглом (Putin Digests, 2014). Безжалісний характер сатири примножується тим, шо Путін зображений оголеним, що, безумовно, грає на понижуючу дискурсивну стратегію. Читач, як на рентгені, бачить усе нутро зображуваного. Україна, Молдова, Латвія, Литва, Естонія, Грузія, потрапивши у рот Путіну, пройшовши стравоходом і кишківником, виходять назовні у вигляді СРСР. Відразу автора до новоствореного об'єднання підкреслюють мухи, що позліталася над ним.

На черговій карикатурі Д. Кейгла Путін виступає у ролі ляльковика, який керує бойовиками, які $є$ слухняною зброєю у його руках. Автор демонструє зразок використання брехливої риторики Кремля щодо збиття малайзійського пасажирського літака (Putin Plane and Ukraine, 2014). Взірець маніпуляції інформаційним простором показано художником на єдиному малюнку, де уособленням Росії виступає не В. Путін, а двоголовий російський орел (Two Faced Russian Seal, 2014). Одна голова хижого птаха спонукає населення розпочати громадянську війну в Україні, а друга застерігає українську сторону не допустити громадянської війни. Обидві карикатури - сатиричне звинувачення Росії у веденні «гібридної війни» проти України, важливими елементами якої є спеціальні інформаційні операції, цільовий психологічний тиск на місцеве населення, дезінформація і маніпулювання фактами, замовчування незручних для РФ подій, тенденційний підбір фактів і «свідків подій» тощо (Юськів, 2017, с. 30-31).

Остання карикатура Д. Кейгла, на якій варто зупинитися, має назву «Україна і 45-кілограмовий доходяга» (Ukraine 98, 2014). Вона сюжетно базується на епізоді з біографії легендарного американського творця бодибілдингу Чарльза Атласа (Анджело Сициліано). Будучи замолоду кволим фізично (сам себе називав 97-фунтовим слабаком), він вирішив стати сильним чоловіком після неприємного епізоду на пляжі, коли він на очах у своєї дівчини не зміг належним 
чином відповісти хулігану, який ногою сипонув йому в обличчя піском. Зайнявшись фізичними вправами, Ч. Атлас таки зміг дати відкоша своєму кривднику. Історія знайшла своє відображення у численних піснях, фільмах, книгах, телепередачах і коміксах. Використане в карикатурі кліше вперше прозвучало в одному 3 них «Mystery in Space», де головний герой Comet говорить, що фізично перед обличчям космічних ворогів він почувається як 98-фунтовий слабак, але психологічно - як Чарльз Атлас на пляжі (The Official Website). На малюнку Деріла Кейгла відбулися деякі перестановки: роль пляжного хулігана відіграє В. Путін, який, граючи біцепсами, шпурляє піском просто в око Україні, яку уособлює жінка, одягнена в купальник національних кольорів. Її компаньйон по відпочинку президент США Барак Обама - попри те, що сам виглядає як кволий слабодух, радить Україні натренувати м'язи. Таким чином, художник апелює і до непідготованості України для захисту своїх національних інтересів і до недостатності американських зусиль у підтримці України під час іiї конфлікту з Росією.

Висновки. Характеризуючи всі проаналізовані карикатури, можемо відзначити такі їх спільні особливості, як чітко виражена, незалежно від національної приналежності художника, антиросійська позиція; однозначні трактування найважливіших подій російсько-українського конфлікту 2014 - 2019 рр., представлення України як жертви російської агресії; підкреслення злочинного характеру дій В. Путіна та російських військ у Криму та на Сході України; виражений гендерний дискурс малюнків (Україна репрезентується як жінка, Росія як чоловік (найчастіше - В. Путін), створюючи бінарну опозицію «слабкість - сила»).

\section{Використані посилання}

Катола В. (2017), Жанрова специфіка української сатиричної зображальної публіцистики на тему російської агресії, Medianpocтір, Вип. 10, С. 92-96.

Питльована Л. (2016), «Українська та світова безпека 20142016 років у політичній карикатурі Iнтернет-ресурсу CAGLE CARTOONS», Виклики політики безпеки: історія та сучасність»: Збірник тез доповідей Міжнародної наукової конференції, НАСВ, Львів, 16-18 червня, 2016, С. 136-137.

Підсумки року: політичні карикатуристи залишаються у небезnеціi, доступно на https://ukrainian.voanews.com/a/journalismdangerous- cartoonists-/4720317.html [Датазвернення 01 березня 2019]. 
Секрет актуальності карикатуриста в еру соиіальних мереж, Available at: https://ukrainian.voanews.com/a/cartoonists-stayingrelavent-social-media-/4817572.html [Accessed 01 March 2019].

Ходаківський М. Д. (2015), До питання про постмодерністські основи збройної агресії Російської Федерації проти України, Правова держава, Вип. 26, С. 478-487.

Яцимірська М. (2015), Візуальні тексти в соціальних мережах (рефлексії, концепти, емоції), Вісник Львівського університету, Сер. Журналістика, Вип. 40, С. 342-350.

Юськів Б.М., Хомич С.В. (2017), Роль медіа-пропаганди в умовах «гібридної війни», Актуальні проблеми міжнародних відносин: Збірник наукових пращь, Вип. 132, Київ: Київський національний університет імені Тараса Шевченка. Інститут міжнародних відносин, С. 27-43.

Caveman Putin Claims Ukraine by Daryl Cagle, USA. 16.03.2014. Available at: http://www.caglecartoons. com/viewimage. asp? $\mathrm{ID}=\{\mathrm{B} 1 \mathrm{EA} 2163-7 \mathrm{C} 80-4 \mathrm{CB} 5-\mathrm{B} 9 \mathrm{E} 7-77 \mathrm{E} 6 \mathrm{BD} 3758 \mathrm{BC}\} \quad$ [Accessed 01 March 2019].

Crimea Referendum by Patrick Chappatte, Switzerland. 10.03.14. Available at: http://www.caglecartoons.com/viewimage.asp? $\mathrm{ID}=\{634 \mathrm{DCABA}-\mathrm{EBD} 9-4 \mathrm{D} 1 \mathrm{~A}-8 \mathrm{D} 0 \mathrm{E}-\mathrm{BBB} 4 \mathrm{D} 6 \mathrm{~F} 81 \mathrm{FE} 9\}$

[Accessed 01 March 2019].

Czar in Sheep's Clothing by Taylor Jones, USA. 29.01.2015. Available at: https://www.caglecartoons.com/viewimage.asp? $\mathrm{ID}=\{5 \mathrm{~F} 944 \mathrm{~B} 43-77 \mathrm{CB}-49 \mathrm{D} 7-9 \mathrm{DA} 3-\mathrm{B} 48537 \mathrm{ECA} 585\}$ [Accessed 01 March 2019].

Daryl Cagle bio, Available at: https://darylcagle.com/bio/ [Accessed 01 March 2019].

EU, Ukraine and Russia by Alexander Zudin, Russia. 03.03.2015. Available at: https://www.cagle.com/alexandr-zudin/2015/03/euukraine-and-russia [Accessed 01 March 2019].

Flight MH17 investigation by Tom Janssen, The Netherlands. 28.09.2016. Available at: https://www.caglecartoons.com/viewimage.asp? $\mathrm{ID}=\{9 \mathrm{D} 67156 \mathrm{C}-\mathrm{DD} 7 \mathrm{~A}-4700-\mathrm{A0B} 4-\mathrm{FFCEDE790D0A}\} \quad$ [Accessed 01 March 2019].

Humanitarian mission by Arend van Dam, the Netherlands. 06.08.14. Available at: https://www.cagle.com/arend-van-dam/2014/08/ humanitarian-mission [Accessed 01 March 2019]. 
Innocence, by Joep Bertrams, the Netherlands, 29.09.2016. Available at: https://www.caglecartoons.com/viewimage.asp? $\mathrm{ID}=\{$ 52D163EE-B4AD-4EB0-A654-DDC208A8D88C $\}$ [Accessed 01 March 2019].

MH17 and Putin By Tom Janssen, the Netherlands, 21.07.14. Available at: https://www.caglecartoons.com/viewimage.asp? $\mathrm{ID}=\{\mathrm{C} 4333436-\mathrm{DCA} 8-4795-\mathrm{B} 49 \mathrm{C}-518 \mathrm{~F} 8 \mathrm{D} 9 \mathrm{~A} 9 \mathrm{D} 1 \mathrm{~F}\} \quad$ [Accessed 01 March 2019].

MH17 looting by Peter Broelman, Australia. 26.07.2014. Available at: https://www.caglecartoons.com/viewimage.asp?ID=\{D1E13A16F425-492E-B183-5D97D5AD6FB9\} [Accessed 01 March 2019].

The Official Website of Charles Atlas. Available at: https://www.charlesatlas.com/licensing.html [Accessed 01 March 2019].

OSCE hostages by Arend van Dam, the Netherlands. 28.04.14. Available at: https://www.cagle.com/arend-van-dam/2014/04/oscehostages [Accessed 01 March 2019].

Putin and Ukraine marshmallows by Daryl Cagle, USA. 19.02.2014. Available at: http://www.caglecartoons.com/viewimage.asp? $\mathrm{ID}=\{1 \mathrm{EF} 161 \mathrm{BA}-9 \mathrm{EA} 9-4 \mathrm{DBB}-844 \mathrm{C}-871786 \mathrm{DEA} 4 \mathrm{DD}\} \quad$ [Accessed 01 March 2019].

Putin and Ukraine separatists by Tom Janssen, the Netherlands. 24.07.2014. Available at: http://www.caglecartoons.com/viewimage.asp? $\mathrm{ID}=\{$ DC6783E1-C39D-4DB4-A121-2ACE0D11F974 $\}$ [Accessed 01 March 2019].

Putin Digests by Daryl Cagle, USA. 31.03.2014. Available at: http://www.caglecartoons.com/viewimage.asp?ID=\{0D5BDE02-ABAE 4219-BFA6-16CCF263DF5A] [Accessed 01 March 2019].

Putin dominates by Pat Bagley, USA. 03.09.14. Available at: https://www.caglecartoons.com/viewimage.asp?ID $=\{4 \mathrm{~B} 8 \mathrm{~F} 68 \mathrm{BE}-$ 7EBD-4F62-9426-6BC64D95D464\} [Accessed 01 March 2019].

Putin Oscar by Dave Granlund, USA. 19.02.15. Available at: http://www.caglecartoons.com/viewimage.asp?ID $=\{610 F 3 E F A-33 C 3-$ 4209-A344-47903D3F72DE] [Accessed 01 March 2019].

Putin Plane and Ukraine by Daryl Cagle. 21.07.2014. Available at: http://www.caglecartoons.com/viewimage.asp?ID $=\{$ A64846F8-478E4E4A-8D26-6AEDD7F4D1E0\} [Accessed 01 March 2019].

Putin shares Ukraine by Sergei Elkin, Russia. 25.05.2015. Available at: https://caglecartoons.com/viewimage.asp? ID $=\{$ FD731D17F4AD-4FF7-BC7D-2CE66A87EB44\} [Accessed 01 March 2019]. 
Putin stalks his prey ву Taylor Jones, USA. 13.02.15. Available at: http://www.caglecartoons.com/viewimage .asp? $\mathrm{ID}=\{550 \mathrm{FF} 65 \mathrm{C}-\mathrm{BB} 6 \mathrm{C}-$ 4CA4-82C0-1BCA013811CA\} [Accessed 01 March 2019].

Putin Tears Ukraine by Daryl Cagle, USA. 09.12.2013. Available at: $\quad$ http://www.caglecartoons.com/viewimage.asp?ID $=\{$ F12E9B4B8E7D-4578-A96C-BB756AC86F2A\} [Accessed 01 March 2019].

Putin Ukraine and Olympic Sponsors by Daryl Cagle, USA. 12.03.2014. Available at: http://www.caglecartoons.com/viewimage.asp? $\mathrm{ID}=\{05 \mathrm{~F} 6 \mathrm{E} 5 \mathrm{DD}-\mathrm{A} 081-4 \mathrm{E} 86-8979-2 \mathrm{E} 3 \mathrm{E} 37895 \mathrm{FDF}\} \quad$ [Accessed 01 March 2019].

Putin - Ukraine Purse Bandit by Daryl Cagle, USA. 06.03.2014. Available at: http://www.caglecartoons.com/viewimage.asp? $\mathrm{ID}=\{\mathrm{D} 2 \mathrm{CA} 4 \mathrm{DB} 2-\mathrm{D} 1 \mathrm{~B} 2-4 \mathrm{E} 01-\mathrm{A} 5 \mathrm{C6}-3 \mathrm{~F} 3 \mathrm{~F} 689 \mathrm{D} 7053\}$ [Accessed 01 March 2019].

Russian aid to Ukraine by Dave Granlund, USA. 28.08.2014. Available at: http://www.caglecartoons.com/viewimage.asp? $\mathrm{ID}=\{\mathrm{E} 0 \mathrm{~F} 43 \mathrm{~B} 8 \mathrm{E}-1 \mathrm{CF} 2-4 \mathrm{~B} 2 \mathrm{~F}-\mathrm{B} 230-4 \mathrm{~A} 8698 \mathrm{~B} 8 \mathrm{D} 0 \mathrm{DF}\} \quad$ [Accessed 01 March 2019].

Russian appetite by Martin Sutovec, Slovakia. 10.04.2014. Available at: http://www.caglecartoons.com/viewimage.asp? ID $=\{3493 \mathrm{DEE} 0-$ B8E3-435D-8E43-7203F98A1BD9\} [Accessed 01 March 2019].

Russian Bear by Nate Beeler, USA. 21.03.14. Available at: https://www.caglecartoons.com/viewimage.asp?ID=\{396A110B-1153422C-849F-13347C20991A] [Accessed 01 March 2019].

Russian Economy by Paresh Nath, UAE. 26.10.2014. Available at: https://www.caglecartoons.com/viewimage.asp?ID $=\{$ 9FCAE2F40D12-4D5B-9725-D3B33E8D2781\} [Accessed 01 March 2019].

Russian humanitarian convoy by Arend van Dam, the Netherlands. 12.08.14. Available at: https://www.cagle.com/arend-van-dam/ 2014/08/ russian-humanitarian-convoy [Accessed 01 March 2019].

Russian tourists by Arend van Dam, the Netherlands. 01.09.14. Available at: https://www.cagle.com/arend-van-dam/2014/09/russiantourists [Accessed 01 March 2019].

Shadow Over Ukraine by Daryl Cagle, USA. 04.03.2014. Available at: http://www.caglecartoons.com/viewimage.asp? $\mathrm{ID}=\{$ A5FFC281-F08E4826-A1B0-6C95DA84DB3A\} [Accessed 01 March 2019].

South stream by Alexander Zudin, Russia. 2.12.14. Available at: https://www.cagle.com/alexandr-zudin/2014/12/south-stream [Accessed 01 March 2019]. 
Thief Putin by Martin Sutovec, Slovakia. 06.03.2014. Available at: http://www.caglecartoons.com/viewimage.asp? $\mathrm{ID}=\{$ A181C798-7D6D493F-B9D9-575538E80322\} [Accessed 01 March 2019].

Tornoe R., Digital Funnies, Available at: https://www. editorandpublisher. com /feature/digital-funnies/ [Accessed 01 March 2019].

Two Faced Russian Seal by Daryl Cagle. 08.04.2014. Available at: http://www.caglecartoons.com/viewimage.asp?ID $=\{12 \mathrm{~A} 81 \mathrm{~B} 30-3 \mathrm{DDE}-$ 4EA3-B251-9CDFB2FA58AC \} [Accessed 01 March 2019].

Ucraine by Pavel Constantin, Romania. 20.02.2014. Available at: http://www.caglecartoons.com/viewimage.asp?ID $=\{962 \mathrm{E} 1173-9 \mathrm{E} 7 \mathrm{D}-$ 4FD5-83CD-9E86C93939C0 [ [Accessed 01 March 2019].

Ukraine 98 Pound Weakling by Daryl Cagle. 01.09.2014. Available at: http://www.caglecartoons.com/viewimage.asp?ID $=\{4 \mathrm{C} 9 \mathrm{E} 437 \mathrm{~A}-$ E12C-42FC-B51A-22D6736C4A1A] [Accessed 01 March 2019].

Ukraine and the bear by Tom Janssen, The Netherlands. 25.02.2014. Available at: https://www.caglecartoons.com/viewimage.asp? $\mathrm{ID}=\{1515 \mathrm{~A} 76 \mathrm{E}-87 \mathrm{~A} 3-4766-\mathrm{B} 467-\mathrm{BDA0BBFB573C}\}$ [Accessed 01 March 2019].

Ukraine redrawing borders by Patrick Chappatte, Switzerland. 8.03.2014. Available at: http://www.caglecartoons.com/viewimage.asp? $\mathrm{ID}=\{\mathrm{DEB} 00148-\mathrm{E} 175-4904-9916-7 \mathrm{DC} 6 \mathrm{D} 3200339\} \quad$ [Accessed 01 March 2019].

Vladimir by Schot, De Volkskrant, Netherlands. 23.07.2014. Available at: https://www.caglecartoons.com/viewimage.asp? $\mathrm{ID}=\{\mathrm{A} 4991302-07 \mathrm{CF}-4 \mathrm{DB} 9-89 \mathrm{CC}-\mathrm{C} 2 \mathrm{CB} 69377 \mathrm{DBE}\} \quad$ [Accessed 01 March 2019].

War of sanctions by Paresh Nath, UAE. 27.03.14. Available at: https://www.caglecartoons.com/viewimage.asp?ID $=\{$ DE1CBC1B-787142D8-8CCD-B670012E6D96\} [Accessed 01 March 2019].

\section{References}

Caveman Putin Claims Ukraine by Daryl Cagle, USA. 16.03.2014. Available at: http://www.caglecartoons.com/viewimage.asp? $\mathrm{ID}=\{\mathrm{B} 1 \mathrm{EA} 2163-7 \mathrm{C} 80-4 \mathrm{CB} 5-\mathrm{B} 9 \mathrm{E} 7-77 \mathrm{E} 6 \mathrm{BD} 3758 \mathrm{BC}\}$ [Accessed 01 March 2019].

Crimea Referendum by Patrick Chappatte, Switzerland. 10.03.14. Available at: http://www.caglecartoons.com/viewimage.asp? $\mathrm{ID}=\{634 \mathrm{DCABA}-\mathrm{EBD} 9-4 \mathrm{D} 1 \mathrm{~A}-8 \mathrm{D} 0 \mathrm{E}-\mathrm{BBB} 4 \mathrm{D} 6 \mathrm{~F} 81 \mathrm{FE} 9\}$ [Accessed 01 March 2019]. 
Czar in Sheep's Clothing by Taylor Jones, USA. 29.01.2015. Available at: https://www.caglecartoons.com/viewimage.asp? $\mathrm{ID}=\{5 \mathrm{~F} 944 \mathrm{~B} 43-77 \mathrm{CB}-49 \mathrm{D} 7-9 \mathrm{DA} 3-\mathrm{B} 48537 \mathrm{ECA585}\} \quad$ [Accessed 01 March 2019].

Daryl Cagle bio, Available at: https://darylcagle.com/bio/ [Accessed 01 March 2019].

EU, Ukraine and Russia by Alexander Zudin, Russia. 03.03.2015. Available at: https://www.cagle.com/alexandr-zudin/2015/03/eu-ukraineand-russia [Accessed 01 March 2019].

Flight MH17 investigation by Tom Janssen, The Netherlands. 28.09.2016. Available at: https://www.caglecartoons.com/viewimage.asp? $\mathrm{ID}=\{$ 9D67156C-DD7A-4700-A0B4-FFCEDE790D0A $\}$ [Accessed 01 March 2019].

Humanitarian mission by Arend van Dam, the Netherlands. 06.08.14. Available at: https://www.cagle.com/arend-van-dam/ 2014/08/ humanitarian-mission [Accessed 01 March 2019].

Innocence, by Joep Bertrams, the Netherlands, 29.09.2016. Available at: https://www.caglecartoons.com/viewimage.asp? $\mathrm{ID}=\{$ 52D163EE-B4AD-4EB0-A654-DDC208A8D88C $\}$ [Accessed 01 March 2019].

Katola, V. (2017), Genre Specificity of Ukrainian Satirical Visual Publicism on the Topic of Russian Aggression (by the materials of Internet resources), Mediaspace, Vol. 10, pp. 92-96.

Khodakivskyi M. (2015), On the issue of postmodern basics of armed aggression of the Russian Federation against Ukraine, Legal state, Vol. 26, pp. 478-487.

MH17 and Putin By Tom Janssen, the Netherlands, 21.07.14. Available at: https://www.caglecartoons.com/viewimage.asp? $\mathrm{ID}=\{\mathrm{C} 4333436-\mathrm{DCA} 8-4795-\mathrm{B} 49 \mathrm{C}-518 \mathrm{~F} 8 \mathrm{D} 9 \mathrm{~A} 9 \mathrm{D} 1 \mathrm{~F}\} \quad$ [Accessed 01 March 2019].

MH17 looting by Peter Broelman, Australia. 26.07.2014. Available at: https://www.caglecartoons.com/viewimage.asp?ID=\{D1E13A16F425-492E-B183-5D97D5AD6FB9\} [Accessed 01 March 2019].

The Official Website of Charles Atlas. Available at: https://www.charlesatlas.com/licensing.html [Accessed 01 March 2019].

OSCE hostages by Arend van Dam, the Netherlands. 28.04.14. Available at: https://www.cagle.com/arend-van-dam/2014/04/oscehostages [Accessed 01 March 2019]. 
Putin and Ukraine marshmallows by Daryl Cagle, USA. 19.02.2014. Available at: http://www.caglecartoons.com/viewimage.asp? $\mathrm{ID}=\{1 \mathrm{EF} 161 \mathrm{BA}-9 \mathrm{EA} 9-4 \mathrm{DBB}-844 \mathrm{C}-871786 \mathrm{DEA} 4 \mathrm{DD}\}$ [Accessed 01 March 2019].

Putin and Ukraine separatists by Tom Janssen, the Netherlands. 24.07.2014. Available at: http://www.caglecartoons.com/viewimage.asp? $\mathrm{ID}=\{$ DC6783E1-C39D-4DB4-A121-2ACE0D11F974 $\}$ [Accessed 01 March 2019].

Putin Digests by Daryl Cagle, USA. 31.03.2014. Available at: http://www.caglecartoons.com/viewimage.asp?ID $=\{0 \mathrm{D} 5 \mathrm{BDE} 02-\mathrm{ABAE}-$ 4219-BFA6-16CCF263DF5A] [Accessed 01 March 2019].

Putin dominates by Pat Bagley, USA. 03.09.14. Available at: https://www.caglecartoons.com/viewimage.asp?ID $=\{4 \mathrm{~B} 8 \mathrm{~F} 68 \mathrm{BE}-$ 7EBD-4F62-9426-6BC64D95D464\} [Accessed 01 March 2019].

Putin Oscar by Dave Granlund, USA. 19.02.15. Available at: http://www.caglecartoons.com/viewimage.asp?ID $=\{610$ F3EFA-33C34209-A344-47903D3F72DE\} [Accessed 01 March 2019].

Putin Plane and Ukraine by Daryl Cagle. 21.07.2014. Available at: http://www.caglecartoons.com/viewimage.asp?ID $=\{$ A64846F8-478E4E4A-8D26-6AEDD7F4D1E0\} [Accessed 01 March 2019].

Putin shares Ukraine by Sergei Elkin, Russia. 25.05.2015. Available at: https://caglecartoons.com/viewimage.asp? ID $=\{$ FD731D17F4AD-4FF7-BC7D-2CE66A87EB44\} [Accessed 01 March 2019].

Putin stalks his prey ву Taylor Jones, USA. 13.02.15. Available at: http://www.caglecartoons.com/viewimage.asp? $\mathrm{ID}=\{550 \mathrm{FF} 65 \mathrm{C}-\mathrm{BB} 6 \mathrm{C}-$ 4CA4-82C0-1BCA013811CA] [Accessed 01 March 2019].

Putin Tears Ukraine by Daryl Cagle, USA. 09.12.2013. Available at: http://www.caglecartoons.com/viewimage.asp?ID $=\{\mathrm{F} 12 \mathrm{E} 9 \mathrm{~B} 4 \mathrm{~B}-$ 8E7D-4578-A96C-BB756AC86F2A] [Accessed 01 March 2019].

Putin Ukraine and Olympic Sponsors by Daryl Cagle, USA. 12.03.2014. Available at: http://www.caglecartoons.com/viewimage.asp? $\mathrm{ID}=\{05 \mathrm{~F} 6 \mathrm{E} 5 \mathrm{DD}-\mathrm{A} 081-4 \mathrm{E} 86-8979-2 \mathrm{E} 3 \mathrm{E} 37895 \mathrm{FDF}\} \quad$ [Accessed 01 March 2019].

Putin - Ukraine Purse Bandit by Daryl Cagle, USA. 06.03.2014. Available at: http://www.caglecartoons.com/viewimage.asp? $\mathrm{ID}=\{\mathrm{D} 2 \mathrm{CA} 4 \mathrm{DB} 2-\mathrm{D} 1 \mathrm{~B} 2-4 \mathrm{E} 01-\mathrm{A} 5 \mathrm{C6}-3 \mathrm{~F} 3 \mathrm{~F} 689 \mathrm{D} 7053\}$ [Accessed 01 March 2019].

Pytlovana L. (2016), «2014-2016 Ukrainian and World Security in Political Caricature of the CAGLE CARTOONS site», Security Policy 
Challenges: Past and Present, Proceedings of the International Scientific Conference, NASA, Lviv, June 16- June 18, 2016, p. 136-137.

Results of the year: political caricaturists are still in danger, Available at: https://ukrainian.voanews.com/a/journalism-dangerouscartoonists-/4720317.html [Accessed 01 March 2019].

Russian aid to Ukraine by Dave Granlund, USA. 28.08.2014. Available at: http://www.caglecartoons.com/viewimage.asp? $\mathrm{ID}=\{\mathrm{E} 0 \mathrm{~F} 43 \mathrm{~B} 8 \mathrm{E}-1 \mathrm{CF} 2-4 \mathrm{~B} 2 \mathrm{~F}-\mathrm{B} 230-4 \mathrm{~A} 8698 \mathrm{~B} 8 \mathrm{D} 0 \mathrm{DF}\} \quad$ [Accessed 01 March 2019].

Russian appetite by Martin Sutovec, Slovakia. 10.04.2014. Available at: http://www.caglecartoons.com/viewimage.asp? ID $=\{3493 \mathrm{DEE} 0-$ B8E3-435D-8E43-7203F98A1BD9\} [Accessed 01 March 2019].

Russian Bear by Nate Beeler, USA. 21.03.14. Available at: https://www.caglecartoons.com/viewimage.asp?ID=\{396A110B-1153422C-849F-13347C20991A] [Accessed 01 March 2019].

Russian Economy by Paresh Nath, UAE. 26.10.2014. Available at: https://www.caglecartoons.com/viewimage.asp?ID=\{9FCAE2F40D12-4D5B-9725-D3B33E8D2781\} [Accessed 01 March 2019].

Russian humanitarian convoy by Arend van Dam, the Netherlands. 12.08.14. Available at: https://www.cagle.com/arend-van-dam/2014/08/ russian-humanitarian-convoy [Accessed 01 March 2019].

Russian tourists by Arend van Dam, the Netherlands. 01.09.14. Available at: https://www.cagle.com/arend-van-dam/2014/09/russiantourists [Accessed 01 March 2019].

The secret of the relevance of the cartoonist at the era of social networks, Available at: https://ukrainian.voanews.com/a/cartoonistsstaying-relavent-social-media-/4817572.html [Accessed 01 March 2019].

Shadow Over Ukraine by Daryl Cagle, USA. 04.03.2014. Available at: http://www.caglecartoons.com/viewimage.asp? $\mathrm{ID}=\{\mathrm{A} 5 \mathrm{FFC} 281-$ F08E-4826-A1B0-6C95DA84DB3A \} [Accessed 01 March 2019].

South stream by Alexander Zudin, Russia. 2.12.14. Available at: https://www.cagle.com/alexandr-zudin/2014/12/south-stream [Accessed 01 March 2019].

Thief Putin by Martin Sutovec, Slovakia. 06.03.2014. Available at: http://www.caglecartoons.com/viewimage. asp?ID= A181C798-7D6D493F-B9D9-575538E80322\} [Accessed 01 March 2019].

Tornoe R., Digital Funnies, Available at: https://www. editorandpublisher.com/feature/digital-funnies/ [Accessed 01 March 2019]. 
Two Faced Russian Seal by Daryl Cagle. 08.04.2014. Available at: http://www.caglecartoons.com/viewimage.asp?ID $=\{12 \mathrm{~A} 81 \mathrm{~B} 30-3 \mathrm{DDE}-$ 4EA3-B251-9CDFB2FA58AC \} [Accessed 01 March 2019].

Ucraine by Pavel Constantin, Romania. 20.02.2014. Available at: http://www.caglecartoons.com/viewimage.asp?ID=\{962E1173-9E7D4FD5-83CD-9E86C93939C0\} [Accessed 01 March 2019].

Ukraine 98 Pound Weakling by Daryl Cagle. 01.09.2014. Available at: http://www.caglecartoons.com/viewimage.asp?ID $=\{4 \mathrm{C} 9 \mathrm{E} 437 \mathrm{~A}-$ E12C-42FC-B51 A-22D6736C4A1A] [Accessed 01 March 2019].

Ukraine and the bear by Tom Janssen, The Netherlands. 25.02.2014. Available at: https://www.caglecartoons.com/viewimage.asp? $\mathrm{ID}=\{1515 \mathrm{~A} 76 \mathrm{E}-87 \mathrm{~A} 3-4766-\mathrm{B} 467-\mathrm{BDA0BBFB} 573 \mathrm{C}\} \quad$ [Accessed 01 March 2019].

Ukraine redrawing borders by Patrick Chappatte, Switzerland. 8.03.2014. Available at: http://www.caglecartoons.com/viewimage.asp? $\mathrm{ID}=\{\mathrm{DEB} 00148-\mathrm{E} 175-4904-9916-7 D C 6 D 3200339\} \quad$ [Accessed 01 March 2019].

Vladimir by Schot, De Volkskrant, Netherlands. 23.07.2014. Available at: https://www.caglecartoons.com/viewimage.asp? $\mathrm{ID}=\{$ A4991302-07CF-4DB9-89CC-C2CB69377DBE $\}$ [Accessed 01 March 2019].

War of sanctions by Paresh Nath, UAE. 27.03.14. Available at: https://www.caglecartoons.com/viewimage.asp? $\mathrm{ID}=\{\mathrm{DE} 1 \mathrm{CBC} 1 \mathrm{~B}-$ 7871-42D8-8CCD-B670012E6D96 ] [Accessed 01 March 2019].

Yatsymirska M. (2015), Visual texts in social networks (reflections, concepts, emotions), Visnyk of Lviv University, Series Journalism, Vol. 40, p. 342-350.

Yuskiv B., Khomych S. (2017), The role of media propaganda in the «Hybrid War», Actual problems of international relations: Collected Works, Vol. 132, Kyiv: Kyiv Taras Shevchenko National University. Institute of International Relations, p. 27-43.

\section{Pytlovana L., Burakov Ya.}

UKRAINE, RUSSIA AND GLOBAL SECURITY IN POLITICAL CARTOONS OF DARYL CAGLE AND CAGLE CARTOONS ONLINE RESOURCE

The article describes the features of representation of events in Ukraine since 2004, and the 2014-2019 Russian-Ukrainian armed conflict in political cartoons of American cartoonist Daryl Cagle as well as in internet resource Cagle Cartoons. 
Five hundred twenty caricatures of the resource have been analyzed and systematized according to basic thematic units covered in the subjects of political cartoons. The most common conceptual graphic metaphors, images of Ukraine, Russia and countries of the West reflected in the political cartoons as well as the attitude of cartoonists to the depicted events of the Russo-Ukrainian conflict are analyzed.

The analysis revealed that clearly expressed anti-Russian position, regardless of the nationality of the artists, is the standard features of the cartoons. In all the pictures, Ukraine is represented in the position of a victim of Russian aggression; the criminal nature of President Vladimir Putin's politic and Russian troops actions in Crimea and Eastern Ukraine are emphasized. The plots of the cartoons have a pronounced gender discourse (Ukraine is represented as a woman, Russia - as a man (most often - V. Putin), creating a binary opposition "weakness strength").

Most cartoons regard the Ukrainian-Russian war not only as a local conflict, which menaces to the national interests and security of Ukraine but in a much broader context of European and world security.

Keywords: Cagle Cartoons security, Daryl Cagle, political cartoon, Ukrainian-Russian armed conflict. 